\title{
El discurso de ruptura social del menemismo
}

Hernán Fair

Hernán Fair es Becario del CONICET con sede en el Centro de Estudios del Discurso y las Identidades Sociopolíticas (CEDIS), Universidad Nacional de San Martín. e-mail: herfair@hotmail.com.

\section{Resumen}

El artículo analiza el componente discursivo de ruptura social del fenómeno conocido como "menemismo". Para ello, parte del enfoque de la teoría de la hegemonía de Ernesto Laclau, tomando como eje un corpus discursivo basado en las alocuciones del presidente Carlos Menem durante su primer período de gobierno (1989-1995), y polemizando con las corrientes dominantes, que se centran en la dimensión de orden político, ya sea más orientados hacia el "decisionismo» 0 hacia el "hobbesianismo». Se sostiene que la identidad menemista logrará trascender el puro orden conservador para componer una dimensión de ruptura social. En ese contexto, pone el foco en la importancia clave del Plan de Convertibilidad, plan que logrará "vaciar» su inherente particularismo, para articular una amplia cadena de significantes. En ese contexto, concluye que el discurso de Menem logrará hacer presente un fuerte componente de ruptura o transformación social que logrará consolidar la hasta entonces frágil y endeble hegemonía menemista.
Este trabajo recupera parte de la investigación realizada como tesis de maestría (FLACSO, sede Argentina, 2007). El autor agradece muy especialmente los comentarios, sugerencias y críticas realizadas por Gerardo Aboy Carlés, Sebastián Barros, Paula Biglieri y Marcos Novaro a una versión preliminar; asumiendo, como es de rigor, la responsabilidad por los errores que pueda contener el trabajo.

\section{Summary}

The article analyzes the discursive component of social rupture from the phenomenon known as «menemismo". To this end, it follows Ernesto Laclau's approach about hegemony. Based on a discursive corpus with axis on the speeches from President Carlos Menem during his first term of government (1989-1995), and debating with the dominant perspectives that focuses on the dimension of political order, either more oriented to the "decisionism» or towards the "hobbesianism», the article maintains that the menemist identity will be able to transcend the pure conservative order to compose a dimension of social rupture. In this context, it focuses on the key importance of the Convertibility Plan. According to it, affirms that this plan succeeds in «emptying» its inherent particularism, for articulate a broad chain of signifiers. In this context, it concludes that Menem's speech will be able to display a strong component of rupture or social transformation that achieved to consolidate the heretofore fragile and feeble hegemony of «menemismo». 